Some Professions with Both Male and Female Members in the Presargonic $\mathrm{E}_{2}-\mathrm{MI}_{2}$ Corpus

\author{
Fumi KARAHASHI
}

The Society for Near Eastern Studies in Japan (NIPPON ORIENTO GAKKAI) 


\title{
Some Professions with Both Male and Female Members in the Presargonic $\mathrm{E}_{2}-\mathrm{MI}_{2}$ Corpus
}

\author{
Fumi KARAHASHI*
}

\begin{abstract}
This paper will examine three professions ( $\left(\breve{\mathrm{su}}-\mathrm{i}_{2}, \operatorname{tug}_{2}-\mathrm{du}_{8}\right.$, and $\left.\mathrm{i}_{3}-\mathrm{du}_{8}\right)$ in the Presargonic $\mathrm{E}_{2}$ $\mathrm{MI}_{2}$ Corpus that included both male and female members, with the aim of assessing their socio-economic status and roughly delineating their internal organization. A pattern seems to be discernible, namely that each group was comprised of men who held subsistence land and thus were listed in Type I ration lists, and men and women who held no land but received barley rations every month, and thus were listed in Type II or IV lists. Assuming that the ration lists and land allotment texts reflect the socio-economic status of a receiver, these documents should in turn reflect the workforce hierarchy.
\end{abstract}

Keywords: women, Presargonic, Lagaš, queen's household, $\mathrm{E}_{2}-\mathrm{MI}_{2}$

\section{Introduction}

The so-called Presargonic $\mathrm{E}_{2}-\mathrm{MI}_{2}$ Corpus (ED IIIb), which originated in Girsu in the city-state of Lagaš, contains some 1,800 texts (Foxvog 2011, 59). Many were excavated clandestinely and reached museums in various parts of the world (Paris, Berlin, London, St Petersburg, Copenhagen, US, and so forth) via antiquities dealers in Baghdad (Prentice 2010, 2-5). The majority of the documents are dated to the last three rulers of Presargonic Lagaš, spanning more than twenty years (Visicato 2011, 301; Sallaberger and Schrakamp 2015, 70-74). ${ }^{1}$ The institution that produced these documents was called $\mathrm{E}_{2}-\mathrm{MI}_{2}$ during the reigns of Enentarzi and Lugalanda as well as the first year of Urukagina, and then its designation was changed to $\mathrm{E}_{2}$ ${ }^{\mathrm{d}} \mathrm{Ba}-\mathrm{u}_{2}$. Regardless of its label it was under the responsibility of three successive queens, Dimtur, Baranamtara, and Sasa. Understanding it as the queen's household, I will use the term $\mathrm{E}_{2}-\mathrm{MI}_{2}$, under which $\mathrm{E}_{2}{ }^{\mathrm{d}}{ }^{\mathrm{Ba}} \mathrm{Ba} \mathrm{u}_{2}$ is subsumed. ${ }^{2}$ In this paper three professions ( $\mathrm{s}_{\mathrm{u}}-\mathrm{i}_{2}, \operatorname{tug}_{2}-\mathrm{du}_{8}$, and $\left.\mathrm{i}_{3}-\mathrm{du}_{8}\right)$ that included both male and female members will be examined, with the aim of assessing their socio-economic status and roughly delineating their internal organization. ${ }^{3}$

\footnotetext{
* Professor, Faculty of Letters, Chuo University

Abbreviations used in the present study generally follow the Cuneiform Digital Library Initiative (CDLI; abbreviations are listed at http://cdli.ox.ac.uk/wiki/abbreviations_for_assyriology). Others are as follows: $n \mathrm{~b}=$ the $n^{\text {th }}$ ration; E $n=$ Enentarzi year $n ; \mathrm{ED}=$ Early Dynastic; Erm $=$ Museum Number, State Hermitage Museum, St. Petersburg; L $n=$ Lugalanda year $n ; n \mathrm{~g}=$ the $n^{\text {th }}$ delivery; P $=$ CDLI number; UE $=$ Urukagina Ensi-year; UL $n=$ Urukagina Lugal-year $n$; E, L, UL are placed in italics $(E, L, U E$, and $U L)$ when they are inferred.

1 For $\mathrm{E}_{2}-\mathrm{MI}_{2}$ scribal practice, see Selz 2011; and for the size of the personnel of the $\mathrm{E}_{2}-\mathrm{MI}_{2}$ throughout its history, see Selz 2010, 16.

2 CDLI, Beld $(2002,1)$, and Sallaberger and Pruß $(2015,74)$ read $E_{2}-M_{2}$ as $\mathrm{e}_{2}$-munus. It may be so since the word munus meant "queen" in some contexts in this corpus, such as šeš munus "queen's brother," nin munus "queen's sister," and ama munus "queen's mother"; cf. Bartash 2014.

3 Male and female lamentation singers (gala) and male and female drum players $\left(\mathrm{lu}_{2}\right.$ geme $_{2} \mathrm{ub}_{5}-\mathrm{ku}_{3}$-ga) cannot be included here due to limitations of space, and will be discussed elsewhere.
} 


\section{Ration Lists and Occupations}

Rations were issued to individuals, and the rations of children were recorded along with those of their mothers. ${ }^{4}$ Deimel $(1928,2)$ classified the barley ration lists from the Presargonic $\mathrm{E}_{2}-\mathrm{MI}_{2}$ corpus into the following four types:

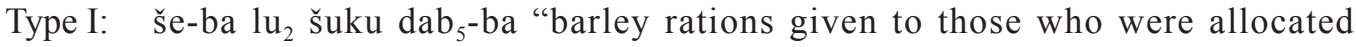
subsistence land"

Type II: $\breve{\text { se-ba igi-nu-du }} \mathrm{il}_{2} \breve{s}_{3}$-dub-didli "barley rations given to blind persons, carriers, and those registered in various tablets"

Type III: še-ba geme ${ }_{2}$-dumu "barley rations given to women and children"

Type IV: še-ba $\mathrm{lu}_{2} \mathrm{di}_{4}-\mathrm{di}_{4}$-la-ne "barley rations given to those of the households of royal children"

Table 1 shows in which type of ration lists male and female members of šu-i $\mathrm{i}_{2}$ "barbers," tug $\mathrm{g}_{2}-\mathrm{du}_{8}$ "rope makers and braiders" (Waetzoldt 2007), ${ }^{6}$ and $\mathrm{i}_{3}-\mathrm{du}_{8}$ "doorkeepers" can be found.

Table 1: Types of Ration Lists and Professions

\begin{tabular}{|c|c|c|c|c|c|}
\hline \multicolumn{3}{|c|}{ Type of Ration List } & \multirow{2}{*}{$\frac{\check{s} \mathrm{u}-\mathrm{i}_{2}}{\mathrm{M}}$} & \multirow{2}{*}{$\frac{\operatorname{tug}_{2}-\mathrm{du}_{8}}{\mathrm{M}}$} & \multirow{2}{*}{$\frac{\mathrm{i}_{3}-\mathrm{du}_{8}}{\mathrm{M}}$} \\
\hline Type I & še-ba $l_{u_{2}}$ šuku dab ${ }_{5}$-ba & & & & \\
\hline \multirow[t]{2}{*}{ Type II } & \multirow{2}{*}{$\begin{array}{l}\text { še-ba igi-nu-du }{ }_{8} \mathrm{il}_{2} \mathrm{s̆a}_{3^{-}} \\
\text {dub-didli }\end{array}$} & $\mathrm{s̆a}_{3}$-dub-e $\mathrm{e}_{2}$-gal & MF & & \\
\hline & & $\mathrm{ša}_{3}$-dub-didli & & MF & MF \\
\hline Type III & \multicolumn{2}{|l|}{ še-ba geme ${ }_{2}$-dumu } & & & \\
\hline Type IV & \multicolumn{2}{|l|}{ še-ba $\mathrm{lu}_{2} \mathrm{di}_{4}-\mathrm{di}_{4}-\mathrm{la}-\mathrm{ne}$} & MF & & $\mathrm{F}^{7}$ \\
\hline
\end{tabular}

$\mathrm{M}=$ male; $\mathrm{F}=$ female

According to Maekawa $(1987,61)$ Type I rations were issued "in each of the last four or five months of the year" as "food supplied at the time of collective projects such as canal construction." 8 Type II, III, and IV rations were issued once a month throughout the year (Maekawa 1987, 51). The people who received Type II, III, or IV rations were also called $\mathrm{lu}_{2}$ iti-da "those of the month" or $l_{2}$ šuku nu-dab ${ }_{5}$-ba "those who were not allocated subsistence land" (Maekawa 1973-74, 105-106). Note, however, that several royal female personnel $\left(\mathrm{ar}_{3}\right.$-tu munus) including $\mathrm{E}_{2}$-mete who held subsistence land were listed in Type II (Maekawa 1973-74, 104 n. 36; Karahashi forthcoming). ${ }^{9}$ It has been understood that these lists reflect in general the socio-economic status of the people listed. According to Selz $(2010,16), \mathrm{lu}_{2} \mathrm{suku} \mathrm{dab}_{5}$-ba belonged to the upper social stratum, igi-nu- $\mathrm{du}_{8}$ and $\mathrm{sa}_{3}$-dub-didli to the lower and middle social

4 Waetzoldt's (1987) comprehensive study of the compensation system in the Ur III period is helpful also for understanding compensation in Presargonic Lagaš.

5 See Prentice 2010, 40 n. 198 on different interpretations of ša ${ }_{3}$-dub-didli that have been proposed by various scholars.

$6 \operatorname{tug}_{2}-\mathrm{du}_{8}$ "rope makers and braiders" will be sometimes abbreviated as "rope makers" for the sake of convenience.

7 Female $\mathrm{i}_{3}-\mathrm{du}_{8}$ are also mentioned in Nik 1 18, which records barley rations distributed to $\mathrm{lu}_{2}$ nam-dumu ${ }^{\mathrm{d}} \mathrm{Ig}$-alimka. Its wording is different from that of Type IV, but nonetheless it refers to the royal children's personnel (see $\S$ V.2 below).

8 However, during UL6, Type I rations were issued every month of the year (Prentice 2010, 20, 78 with n. 338); see also Yamamoto 1981 on holders of subsistence land.

9 For a recent overview of the $\mathrm{E}_{2}-\mathrm{MI}_{2}$ workforce, see Sallaberger and Pruß 2015, 74-80. 
strata, and geme ${ }_{2}$-dumu (including a small number of men) to the lower social stratum. Similarly, "higher ranking members received larger or smaller subsistence fields" (Steinkeller 1999a, 290); and "[p]ersonnel who belonged to the middle and higher ranks, including some craftsmen, could be rewarded with land allotment" (Waezoldt 1987, 118). Maekawa $(1987,58)$ has observed that those who received rations every month (those of Type II and Type IV in our discussion) ${ }^{10}$ were supervised in their daily work by those of Type I, a point to which I will return later.

\section{Male and Female Barbers ( $\breve{s} u-i_{2}$ and šu- $i_{2}$ munus)}

Naturally the work of male and female šu- $\mathrm{i}_{2}$ involved grooming - cutting, shaving, trimming, and coiffuring — of hair. A seal inscription (RIME 2.1.1.2003) tells us that Sargon's daughter Enheduana employed a kind of "coiffeur" (Frayne 1993, 38). A female hairdresser was depicted braiding the hair of the queen of Urkeš (Budin 2011, 187) in a cylinder seal owned by the nurse of the queen's child (Buccellati and Kelly-Buccellati 1995-96, 22). An Ur III text (AOS 32 C1 obv. ii 12) listed a munus šu-i "Barbierin" (Waezoldt 1988, 31 n. 10). ${ }^{11}$ In the Lagaš $\mathrm{E}_{2}-\mathrm{MI}_{2}$ corpus, about twenty-three names of "barbers," both male ( $\left.\breve{s u}-i_{2}\right)$ and female (šu- $i_{2}$ munus), are preserved from the period from Enentarzi year 2 through Lugalanda to the end of Urukagina lugal-year $6 .{ }^{12}$ Our texts, however, do not reveal any of their professional duties. Since it is impossible to distinguish a barber from a hairdresser or vice versa, I use the word "barber" as a general term, to which "male" or "female" will be added.

In the following I will examine the socio-economic status and activities of those in this profession and argue that they can be placed in three groups under the $\mathrm{E}_{2}-\mathrm{MI}_{2}$ administration. One group consisted of landed male barbers belonging to higher socio-economic strata. The other two groups were landless male and female barbers, one group working for the palace/ $\mathrm{E}_{2}-\mathrm{MI}_{2}$, and the other for the royal children's households. ${ }^{13}$

\section{Male Barbers with Land}

At least four male barbers appear in the corpus in conjunction with subsistence land.

\section{Lugal-temen}

Lugal-temen was certainly one of the most prominent barbers in the $\mathrm{E}_{2}-\mathrm{MI}_{2}$ corpus. He was first mentioned in BIN 8347 (E2), which was the record of barley-emmer rations (še-ba ziz 2 -ba) distributed to $\mathrm{lu}_{2}$-igi-nigin ${ }_{2}$ sub-lugal-ke $\mathrm{k}_{4}$-ne "the palace/ $\mathrm{E}_{2}-\mathrm{MI}_{2}$ personnel and the core military

\footnotetext{
${ }^{10}$ There are no šu- $\mathrm{i}_{2}, \operatorname{tug}_{2}-\mathrm{du}_{8}$, or $\mathrm{i}_{3}-\mathrm{du}_{8}$ in Type III.

${ }^{11}$ Ur III texts mostly use šu-i, with sporadic use of šu- $i_{2}$. For an example of the Ur III $i_{2}$, see Molina 2008,130 no. 3 rev. 7 (here the sign $\mathrm{I}_{2}$ is the sign $\mathrm{I}$ turned almost $90^{\circ}$ clockwise).

${ }^{12}$ Excluded from our discussion are two barbers listed among the witnesses in a sale document of a house sold by a woman from an earlier period (Hallo 1973, 238, 11. 51-53: ${ }^{\mathrm{I}}$ Lugal-igi-tab / ${ }^{\mathrm{I}} \mathrm{E}-\mathrm{da}-\mathrm{hul} / \breve{\mathrm{su}} \mathrm{i}_{2}-\mathrm{me}$ ). The date of the composition was expressed as "at that time... Dudu was sanga-priest" $(11.65,68)$ and can be safely placed during the reign of Enmetena, since a text (RIME 1.9.5.27) reads "his (= Enmetena's) servant Dudu, the temple administrator (sanga) of the god Ningirsu" (iii 1-3); see Maekawa 1973-74, 137-138 with n. 82, on Dudu and the placing of his tenure as the sanga of Ningirsu just before Enentarzi.

${ }^{13}$ On barbers of other time and place, see Kleinerman 2013 (Ur III Iri-Sagrig); Pecha 2011 (Old Babylonian period).
} 
and labor force" (Maekawa 1973-74, 110) ${ }^{14}$ for the occasion of the festival of the goddess Bau: he was given 36 sila of barley and 36 sila of emmer - 72 sila in total. He occurs again receiving 36 sila of barley and 36 sila of emmer in another list of barley-emmer rations of the festival of Bau (DP 127), ${ }^{15}$ dispensed, this time, to the group starting with the elite members of society, such as the ereš-dingir-priestess of the goddess Bau, ${ }^{16} \mathrm{Geme}_{2}-\mathrm{ub}_{5}-\mathrm{ku}_{3}$-ga, the queen's mother, ${ }^{17}$ and sisters of the ruler. That Lugal-temen held parcels of leased (apin-la $a_{2}$ land is attested in three documents. In E3, 2 and 3/4 iku of taxable newly cultivated land $\left(\mathrm{gan}_{2} \mathrm{su}_{3}\right.$-la-maš) ${ }^{18}$ was measured out $\left(\mathrm{gid}_{2}\right)$ for him (VS 2561 iii 2-3); ${ }^{19}$ in L1, he paid two goats as tax on the field leased from the ruler (VS 2712 i 1-2); ${ }^{20}$ and in L3, he received 3 iku of ki-uzug ${ }_{5}$-field from Lugalanda's subsistence land (šuku Lugal-an-da) (VS 2540 i 1-3). ${ }^{21}$

A certain Lugal-temen had a kind of living or working arrangement with some of the barbers of the households of Urukagina's children for about two years (UL2.[ ]b-4.7b): $\mathrm{NP}_{1+n}$ Lugaltemen-da e-da-ti/ $/ \mathrm{se}_{12}{ }^{22}$ Although this Lugal-temen was not given an occupational title, it is not unreasonable to identify him with the barber Lugal-temen, especially because those who were assigned to live/work with him were all barbers (for more details, see below).

\section{Igi-zi(-bar-ra)}

Igi-zi is surely the best-attested barber of those discussed in this paper. On one occasion his name was written in a longer form, Igi-zi-bar-ra / šu-i ${ }_{2}$ (DP 624 i 5-6; dated to L3). ${ }^{23}$ This document, dealing with the work of canal maintenance that was one of the duties of šuku-field holders (Maeda 1984), assigned to him the work along a 4 gi (= ca. $12 \mathrm{~m}$ ) length of the canal. ${ }^{24} \mathrm{He}$ was also mentioned in the so-called "pure milk pure malt" texts. ${ }^{25}$ In this - perhaps a ceremonial gift exchange (Selz 1995, 73) or a transfer (Magid 2001, 314 n. 6) - pure milk and malt was given by one person to another, and the majority of both givers and receivers seemed to belong to higher social strata (Prentice 2010, 181). Igi-zi the barber was listed as eighth among the givers. In L5 (BIN 8353 ii 7-8) and L6 (VS 2541 v 3-4), he carried out a crop-related task, another duty of

${ }^{14}$ Cf. “Gerstzuteilungen (und) Emmerzuteilungen für die Leute (von) 'Ansehen,' (und zwar)? die Untergebenen des Königs" (Selz 1993, 545).

${ }^{15}$ DP 127 is dated to Lugal-an-da-nu-hun-ga (= Lugalanda) but no year is given. According to Selz (1995, 24), Lugalan-da is a short form for Lugal-an-da-nu-hun-ga "der König, der sich für An nicht beruhigt"; for more discussion, see Selz 1989, 544.

${ }^{16}$ Possibly the queen herself was the ereš-dingir-priestess of the goddess Bau (Maekawa 1996, 179; Sallaberger and Huber-Vulliet 2005, 636; Suter 2007, 328; Goodnick Westenholz 2013, 260-261); cf. Steinkeller 1999b, 120 n. 54.

${ }_{17}$ She was referred to as ama munus in VS 2781 i 3-4.

18 "Abgabepflichtiges Newbruchfeld" (Selz 1989, 192).

${ }^{19}$ Courtesy of Selz.

${ }^{20}$ Courtesy of Selz.

${ }^{21}$ Courtesy of Selz.

${ }^{22}$ The verb ti is used for the singular subject and the verb $\mathrm{se}_{12}$ for the plural subject; Maekawa $(1973-74,122 \mathrm{n}$. 74) interprets the expression as "work under the direction of someone (-da-)"; see also Magid 2001 and n. 55 below.

23 A person named Nin-mu-ma- $<\mathrm{da}>-\mathrm{ag}_{2}$ who was listed preceding Igi-zi-bar-ra may or may not be identical to the barber Nin-mu-ma-da-ag ${ }_{2}$ (see below).

${ }^{24}$ Regarding the šuku-field holders, Maekawa $(1973-74,88)$ writes, "[p]laying a central role in collective labor or war, the $\mathrm{lu}_{2}-\mathrm{kur}_{6}-\mathrm{dab}_{5}$-ba formed the backbone of the city."

${ }^{25}$ VS 14173 (L4), DP 226 (L4), and DP 132 (L5): documents were classified as $l_{2}$ igi-nigin ${ }_{2} \mathrm{lu}_{2} \mathrm{ga} \mathrm{ku}_{3} \mathrm{munu}_{4}-\mathrm{ku}_{3}$ bame “"Leute von Ansehen,' Leute, die (kultisch) reine Milch (und) reines Malz schenken, sind sie" (Selz 1995, 74). It was dubbed "the malted-milk offering" in the classroom by Gelb $(1975,72)$, but "not too seriously." 
$\check{s} u k u$-holders, on behalf of the ruler.

From UL3.12b to UL4.10b, Igi-zi the barber was listed in Type IV ration lists and repeatedly received 72 sila of barley. ${ }^{26}$ In UL4 (DP 563 ii 2-3, rev. i 2), he provided 620 sila of barley for the purchase of low-quality wool ( $\check{e}$ siki mug-a $\mathrm{sa}_{10}-\mathrm{a}-\mathrm{am}_{6}$ ). His status as a holder of subsistence land is again clearly shown by texts dated to UL6: 1/2 iku (DP 584 rev. i 3-4) or 1 iku (MLVS 8 rev. iii 7-8). Furthermore, four Type I lists mention him as receiving 72 sila. ${ }^{27}$ Although the original classification of the document is not preserved, Erm 14349 [P225756] that contains 0.2.0 Igi-zi / šu-i ${ }_{2}$ (rev. ii 5-6) may well belong to the Type I group.

\section{Šeš-kur-ra}

VS 1472 (L4), whose classification reads $\mathrm{GAN}_{2}$ šuku še $\mathrm{mu}_{2}$-a gid ${ }_{2}$-da $\mathrm{lu}_{2}$ didli "barley planted subsistence land - measured out — of various people," recorded that $9 \mathrm{iku}$ of land was measured out to Šeš-kur-ra (rev. i 1-2). ${ }^{28}$ In a text dated to L6 he appeared carrying out a certain administrative task, probably overseeing the transportation of ten beams that En-ig-gal, the chief administrator of the $\mathrm{E}_{2}-\mathrm{MI}_{2}$, had taken out of a certain storehouse (DP 465 i 1-ii 4).

\section{En-ud-da-na}

DP 591 ii 9-iii 3 reads: "Šubur the smith received a parcel of barley planted subsistence land measuring $3 \frac{1}{2} \mathrm{iku}$, (previously) held by Enudana the barber."

\section{Male Barbers with Administrative Tasks}

While Šeš-kur-ra, discussed above, is attested as both holding land and engaging in activity other than that of barber, the following three barbers are only found performing administrative tasks. These barbers are considered here as belonging to a higher socio-economic strata likewise those discussed above who held subsistence land.

\section{Ur-sag}

A text reports that Ur-sag together with other individuals played the role of deputy (maškim) in a kind of transaction(?) involving barley (Erm 14371 ii 4-6) [P225758]. ${ }^{29}$

\section{Lugal-ma-tum}

In the festival of Bau in L3, three people brought with them various goods as "the offerings of the ruler (nig ${ }_{2}$-giš-tag ensi ${ }_{2}$-ka) to the ki-a-nag ${ }^{30}$ for Enentarzi”" (RTC 60 rev. i 5-ii 3). Lugal-matum $_{2}$ the barber was listed as the first among these three people (ii 4-iii 2).

\footnotetext{
${ }^{26}$ HSS 327 vi 11-12; Nik 116 vi 4-5; DP 116 vii 12-13; DP 117 vii 4-5; DP 118 vii $11-12$. As the date of DP 118 , which is not preserved, CDLI suggests "UL5(?)."

${ }^{27}$ DP 121 rev. ii 10-11 (UL6.6b); BIN 8354 rev. ii 5-6 (UL6.9b); HSS 313 rev. ii 7-8 (UL6.10b); HSS 312 rev. ii 8-9 (UL6.11b).

${ }_{28}^{28}$ For še $\mathrm{mu}_{2}$-a, gid $_{2}$, and other šuku-field-related terminology, see Yamamoto 1980.

${ }^{29}$ For this text, see also $\S$ IV.1 below.

${ }^{30}$ The mortuary chapel (Jagersma 2007, 296); the feast in honor of the dead (Brunke 2011, 177).
} 


\section{Nin-mu-ma-da-ag}

A document dating from L4 (DP 199) reports that the barber Nin-mu-ma-da-ag 2 brought with him from the animal fattener (kurušda) two sheep that were meant to be Baranamtara's offering. The name Nin-mu-ma-da-ag ${ }_{2}$ could be a woman's name. ${ }^{31}$ In fact Rosengarten $(1960,244)$ interpreted this person as a woman and translated "la coiffeuse N." This Nin-mu-ma-da-ag ${ }_{2}$, however, was probably male, based on DP 111 (E4). In DP 111, a certain barber named Nin-

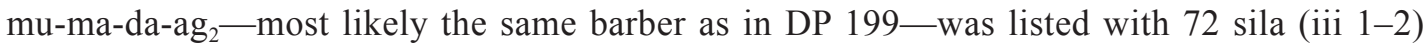
and counted in the sum ( $\mathrm{su}$-nigin $\left._{2}\right)$ section as the only person $\left(1 \mathrm{lu}_{2}\right)$ who received the highest amount, 72 sila, of barley (rev. ii 4); meanwhile 18 women (DP 111 iii 5-rev. ii 3) were counted as 18 female servants $\left(\right.$ geme $_{2}$ ), each receiving 18 sila (rev. ii). ${ }^{32}$ Hence, the barber Nin-mu-mada-ag ${ }_{2}$ in DP 111 was in all likelihood a man. ${ }^{33}$

\section{Male and Female Barbers During the Reign of Enentarzi Nin-mu-ma-da-ag 2 (see above)}

\section{Nin- $u_{3}-m a$ and Nin-al-mah}

DP 176 (E3), recording wool rations given to the household personnel of Dimtur, DP 110 (E3.12b), and DP 111 (E4.6b), the latter two also recording barley rations for Dimtur's personnel, contain lists of 33, 46, and 35 men and women, respectively. ${ }^{34}$ Generally speaking men in these lists are designated by the occupation name or title, while women are referred to only by name, with the exception of the individual(s) designated as šu- $\mathrm{i}_{2}$ :

$$
\begin{aligned}
& \text { Nin- } u_{3}-\text { ma / šu-i }{ }_{2} \text { (DP } 176 \text { rev. iii 3-4) } \\
& \text { Nin- } u_{3}-\text { ma / šu-i }{ }_{2} \text { (DP } 110 \text { rev. ii 6-7) } \\
& \text { Nin- } u_{3}-\text { ma / Nin-al-mah / šu-i }{ }_{2}-m e \text { (DP } 111 \text { rev. i 6-ii 1) }
\end{aligned}
$$

Now, it seems rather inconceivable that "šu- $\mathrm{i}_{2}$ " was meant to apply to all the women (14 or 15) preceding Nin- $\mathrm{u}_{3}-\mathrm{ma}$ or Nin- $\mathrm{u}_{3}-\mathrm{ma}$ and Nin-al-mah on the lists. Even in Urukagina's reign, when the $\mathrm{E}_{2}-\mathrm{MI}_{2}$ organization increased its size (Maekawa 1973-74, 101), the attested number of male and female šu- $\mathrm{i}_{2}$ was around ten (see below for more details). Therefore, the women listed in DP 176, DP 110, and DP 111 should be understood to include all female household workers, as indicated by the rubric of DP 176, "servants/personnel, the property of Dimtur" ( $\mathrm{ar}_{3}$-tu u $\mathrm{u}_{2}$-rum $\operatorname{Dim}_{3}$-tur). ${ }^{35}$ Naturally various specializations were included, with šu- $\mathrm{i}_{2}$ being one of them. It is reasonable to think that in DP 176 and DP 110, šu- $\mathrm{i}_{2}$ refers to Nin- $\mathrm{u}_{3}-\mathrm{ma}$, while in DP 111 , šu- $\mathrm{i}_{2}$ -

\footnotetext{
31 According to Foxvog (2011, 61-62), nin "lady, sister" is one of the gender-specific name incipits, and is borne by 189 females, 4 males, and 7 unknown people in the ED Lagash corpus of 121 names beginning with nin-. Gelb (1975, 72) also observed that a great majority of the names composed with the element nin- are feminine.

32 According to Ellison (1981, 39-40), a monthly diet of 18 sila (= 0.6 sila daily $=0.50$ liters daily) or even 24 sila (= 0.8 sila daily $=0.66$ liters daily) is not an adequate energy intake for a person, male or female; also see Hruška 1988 , 333.

${ }^{33}$ It is true that the term $1 u_{2}$ does not always refer to a male, as can be discerned from DP 176, in which a group of women, $\mathrm{PN}_{\mathrm{f} 1}-\mathrm{PN}_{\mathrm{f} 15}$, are counted as $\mathrm{lu}_{2}$ (for the groups of women in DP 111 and DP 176, see below).

${ }^{34}$ Maekawa (1973-74, 101-109) discussed DP 176, DP 110, and DP 111 in conjunction with the development of the $\mathrm{E}_{2}-\mathrm{MI}_{2}$.

${ }^{35}$ Maekawa (1973-74, 102 n. 30, 107 n. 41, 128-129 with n. 70) discusses some of the women on the list.
} 
me refers to Nin- $\mathrm{u}_{3}-\mathrm{ma}$ and the newly employed Nin-al-mah. In this way, the use of the plural marking -me can be explained.

\section{Male and Female Barbers During the Reign of Lugalanda}

\section{Dar-da, Nin-al-sa $a_{6}$ and Dingir-al-sa 6}

In DP 231 (date broken), a pair of a male and a female barbers, Dar-da and Nin-al-sa $a_{6}$, received 36 sila of barley each (rev. vi $5^{\prime}-7^{\prime}$ ). The text clearly indicates that their rations were the ninth distribution, while the šuku-land holders were receiving their first. In other words, these two barbers did not belong to the šuku-holding class. In addition, a person named Dar-da with no occupation name is listed in DP 110 and DP 111, and someone named Nin-al-sa 6 is mentioned among the female personnel in DP 176, DP 110, and DP 111. It is possible, but cannot be proved, that these two should be identified with the barbers in DP $231 .^{36}$ In another text (DCS 8) dated to Lugalanda-nu-hun-ga 1 (= L1), Dar-da is listed as a barber, together with Dingir-al$\mathrm{sa}_{6}$. Both receive 12 sila of emmer (rev. iv 9-11) in the festival of Bau, which was in the last or penultimate month of the year (Cohen 1993, 38; Beld 2002, 199). There is also a certain Dingiral-sa 6 who repeatedly appears as a barber in the service of the $\mathrm{E}_{2}-\mathrm{MI}_{2}$ after L6 (see below). If this Dingir-al-sa ${ }_{6}$ was the same person as the Dingir-al-sa $\mathrm{s}_{6}$ of DCS 8 and if we assume that Dingir-al$\mathrm{sa}_{6}$ worked continuously, Nin-al-sa ${ }_{6}$ would have preceded him, thus enabling us to place DP 231 before DCS 8 in time. ${ }^{37}$

\section{Dingir-al-sa ${ }_{6},{ }^{d}$ Inanna-men $_{x}\left(-z i-p a_{4}-p a_{4}\right)$, Me-me, and Geme $e_{2}-d u_{6}$}

From L6.9b to UL6.12b, there was a pair of a male and a female barbers who generally received $36 / 48$ sila and 24/18 (once 36) sila of barley rations, respectively. The pair is usually listed by the following formula on the ša ${ }_{3}$-dub-e $e_{2}$ gal "palace tablet" in Type II: (ration amount) $\mathrm{PN}_{\mathrm{m}} /$ nita-am 6 / (ration amount) $\mathrm{PN}_{\mathrm{f}} /$ munus-am 6 / šu- $\mathrm{i}_{2}-\mathrm{me}^{38}$ While $\mathrm{PN}_{\mathrm{m}}$ was always Dingir-al- $\mathrm{sa}_{6}, \mathrm{PN}_{\mathrm{f}}$ changed from ${ }^{\mathrm{d}}$ Inanna-men $_{\mathrm{x}}\left(-\mathrm{zi}-\mathrm{pa}_{4}-\mathrm{pa}_{4}\right)\left(\mathrm{L} 6.9 \mathrm{~b}-\mathrm{UL2}\right.$.8b) ${ }^{39}$ to Me-me (UL3.6b-4.6b) ${ }^{40}$ to $\mathrm{Geme}_{2}-\mathrm{du}_{6}$ (UL5.3b-6.12b). ${ }^{41}$ A document dating from UL3.10b also informs us that some kind of living/ working arrangement was made for Dingir-al-sa 6 and Me-me with $\mathrm{U}_{2}-\mathrm{U}_{2}{ }^{42}$

\section{Barbers Working in Royal Children's Households}

Royal children's households also employed male and female barbers, whose rations were

${ }^{36}$ Cf. Maekawa (1973-74, 102 n. 30), who does not identify the Nin-al-sa ${ }_{6}$ appearing in DP 176, DP 110, and DP 111, with Nin-al-sa 6 the barber in DP 231.

37 As for the date of DP 231, CDLI proposes L1 with reservations, while Maekawa $(1973-74,108)$ proposes the first half of Lugalanda's reign.

${ }_{38}$ Also in a text (P387452 viii 2-6) differently classified as še-ba ša ${ }_{3}$-dub-e 2 -gal ša ${ }_{3}$-dub-didli (UL2.6b).

39 VS 2571 viii 6-10; VS 2511 viii 2-6; RA 71102 viii 12-rev. i 2; MVN 32 viii 11-rev. i 4; Nik 19 vii 4-8; HSS 3 15 vi $14-18$; HSS 316 vii $1-5$; DCS 4 vii $1-5$; FAOS $15 / 2123$ vi $4-8$; P387452 viii $2-6$; DP 113 ix $8-12$. The pair also received wool rations in DP 171 rev. v 9-12, a document classified as siki-ba $\mathrm{lu}_{2} \mathrm{u}_{2}-[\mathrm{rum}]{ }^{\mathrm{d}} \mathrm{Ba}-\mathrm{u}_{2}$.

${ }^{40}$ CT 5036 rev. i 4-10; HSS 317 viii 17-rev. i 6; FAOS 15/2 120 ix 2-6; TSA 14 viii 17-ix 2; FAOS 15/1 2 ix 1-5.

${ }^{41}$ DP 114 ix 10-14; DP 115 rev. i 1-5; TSA 17 ix 9-13; FAOS 15/2 122 rev. i 2-6; TSA 16 viii 13-17; HSS 318 vii 13-viii 3; cf. two texts with a different classification, še-ba geme ${ }_{2}$-dumu igi-nu-du $\mathrm{il}_{2} \mathrm{s̆}_{3}$-dub-didli, dating from UL6.11b (HSS 324 iii 11-12) and UL6.12b (TSA 13 iii 15-16), where Dingir-al-sa ${ }_{6}$ occurs alone by himself.

${ }^{42}$ 0.1.2 Dingir-al-sa 6 / nita-am 6 / 0.0.4 Me-me / munus-am ${ }_{6} /{\mathrm{su} u-\mathrm{i}_{2}-\mathrm{me} / \mathrm{U}_{2}-\mathrm{U}_{2} / \text { e-da-se }}_{12}$ in HSS 317 viii $17-$ rev. i 6. 
recorded in Type IV lists. ${ }^{43}$

\section{Barber of Lugalanda's Child Munus-sa ${ }_{6}$ ga: Lugal-mu-tu}

Lugal-mu-tu was the barber belonging to the household of Munus-sa ${ }_{6}$-ga, Lugalanda's daughter. ${ }^{44}$ He received 24 sila of barley at the ninth(DP 157 rev. ii 9-10), the tenth (VS 2537 rev. i 10-11), and the eleventh(VS 2514 rev. i 7-8) expenditures, all three texts dated to L6.

\section{Barbers of Urukagina's Children}

Seven barbers in total are attested for the three households of Urukagina's children Geme ${ }_{2}-$ ${ }^{\mathrm{d}} \mathrm{Ba}_{2} \mathrm{U}_{2}, \mathrm{Geme}_{2}$-tar-sir 2 - $\mathrm{Sir}_{2}$-ra, and A-en-ra-mu-gi ${ }_{4} / \mathrm{A}-\mathrm{en}-\mathrm{ne}_{2}-\mathrm{ki}_{-}-\mathrm{ag}_{2}{ }^{45}$ from early UL2 to UL5.7b. ${ }^{46}$ There were three to five barbers working at a given time.

\section{Barbers of Geme ${ }_{2}{ }^{d} \mathrm{Ba}-u_{2}:$ Lugal- ${ }^{d} \mathrm{En}-\mathrm{lil} l_{2}-\mathrm{le},{ }^{d} \mathrm{Ba}-\mathrm{u}_{2}$-dingir-mu, and Nin-sag-ga-tuku}

Lugal- ${ }^{\mathrm{d}}$ En-lil ${ }_{2}-\mathrm{le}$ repeatedly received 36 sila, while ${ }^{\mathrm{d}} \mathrm{Ba}-\mathrm{u}_{2}$-dingir-mu received only 18 (once 24 sila) and had a kind of living/working arrangement, at one point, with Lugal-temen, ${ }^{47}$ and the rest of the time with $\mathrm{U}_{2}-\mathrm{U}_{2}{ }^{48}$ As mentioned above ( $\S$ III.1), this Lugal-temen and the barber Lugaltemen were most likely the same person; $U_{2}-U_{2}$ is to be identified as an agrig-official (see n. 53). Sometime between UL3.9b and UL4.10b, ${ }^{\mathrm{d}} \mathrm{Ba}-\mathrm{u}_{2}$-dingir-mu was replaced by Nin-sag-ga - -tuku, who was likewise given 18 (once 24) sila. ${ }^{49}$ No living/working arrangement is reported for the latter.

\section{Barbers of Geme -tar-sir $_{2}$-sir ${ }_{2}-$ ra: Sag-mu-ab-tuku, A-gil-sa, and Igi-zi}

Sag-mu-ab-tuku received 24 (once 30) sila throughout his career, and his one-time female coworker was A-gil-sa, who received the same amount of rations (24 sila). At one point both of them had a kind of living/working arrangement with Lugal-temen (no date preserved). ${ }^{50}$ Sagmu-ab-tuku kept this arrangement until UL4.7b $b^{51}$ and continued working as a barber for at least another year until UL5.7b (Nik 120 vii 4-5). After A-gil-sa's disappearance, Igi-zi entered into the service toward the end of UL3. This Igi-zi, who repeatedly received 72 sila of barley (see $n$. 26), should be identified with Igi-zi, the high-ranking and šuku-holding barber (see $\S$ III.1).

\section{Barber of A-en-ra-mu-gi/A-en-ne ${ }_{2}-k_{1}$-ag ${ }_{2}$ : Nin-igi-ga $a_{2}-t e s ̌-m u / b i$}

The barber's name is written either Nin-igi-ga -teš $_{2}$-mu (five times) or Nin-igi-ga -teš $_{2}$-bi (four

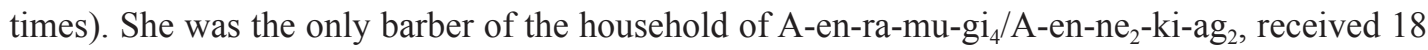

\footnotetext{
43 See Maekawa 1973-74, 131-134, especially n. 74, on the development of this type of ration lists.

${ }^{44}$ Asher-Greve $(1985,152)$ presents the personnel of the daughters of Lugalanda in a tabular form.

${ }^{45}$ Beld $(2002,17)$ sees one person with two names, A-en-ra-mu-gi $i_{4}$ and A-en-ne ${ }_{2}-\mathrm{ki}_{-} \mathrm{ag}_{2}$, while on p. 78 he regards them as two different persons.

${ }^{46}$ In contrast to his three siblings, Šubur- ${ }^{\mathrm{d}} \mathrm{Ba}-\mathrm{u}_{2}$ had no barber listed among his household personnel.

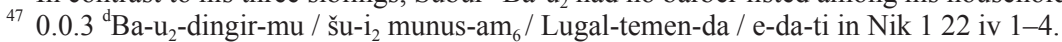

${ }^{48} 0.0 .3{ }^{\mathrm{d}} \mathrm{Ba}_{2} \mathrm{u}_{2}$-dingir-mu / šu- $\mathrm{i}_{2}$ (munus)- $\mathrm{am}_{6} / \mathrm{U}_{2}-\mathrm{U}_{2} /$ e-da-ti in BIN 8359 iii 15-iv 3; HSS 325 iii 15-iv 2; TSA 18 iii 14-17 (0.0.4); HSS 326 iii 12-15; FAOS 15/2 124 iii 12-15; for the name $\mathrm{U}_{2}-\mathrm{U}_{2}$, see Balke 2011, 10 (sub Rs. I 9, II 2); Foxvog 2011, 61.

49 DP 117 iv 6-7; CT 5035 iii 11'-12', iv 1'; DP 118 iv 12-13; FAOS $15 / 120$ iv 6-8.

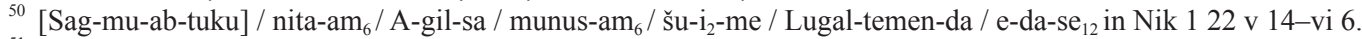

51 0.0.4 Sag-mu-ab-tuku / šu-i ${ }_{2}-\left(\operatorname{am}_{6}\right)$ / Lugal-temen-da / e-da-ti in DP 119; BIN $8359 \mathrm{v}$ 13-vi 1; HSS 3 25; TSA 18; HSS 3 26; FAOS 15/2 124; Nik 1 16; DP 116.
} 
or 24 sila, and presumably had a kind of living/working arrangement with Lugal-temen at one point $^{52}$ and with $\mathrm{U}_{2}-\mathrm{U}_{2}$ the rest of the time, ${ }^{53}$ as did the other female barbers. ${ }^{54}$

\section{Rope Makers ( $\operatorname{tug}_{2}-\mathrm{du}_{8}$ )}

In this category we can recognize, on the one hand, a group that consisted of landed males belonging to higher socio-economic strata and, on the other, a landless male and female working for the $\mathrm{E}_{2}-\mathrm{MI}_{2}$.

\section{Rope Makers from Higher Socio-Economical Strata}

In Type I lists $\operatorname{tug}_{2}-\mathrm{du}_{8}$ professionals were not listed by name but rather with a brief statement telling how many rope makers received how much in rations, such as "72 sila of barley for a rope maker," 55 "four rope makers with 72 sila of barley each," maker, three rope makers with 42 sila of barley each." ${ }^{57}$ This kind of recording convention is also found in texts dealing with work assignments and field allotments of $\operatorname{tug}_{2}-\mathrm{du}_{8}$, such as "2.5 gi (of canal maintaining work assigned to) a rope maker" 58 or "4 $1 / 4 \mathrm{iku}$ of subsistence land (allotted to) a rope maker." ${ }^{, 59}$ Nevertheless we can collect several personal names of tug ${ }_{2}-\mathrm{du}_{8}$ from documents of work assignment and land allotment. For instance, Erm 15776 [P225761] recorded $2 \mathrm{iku}$ of

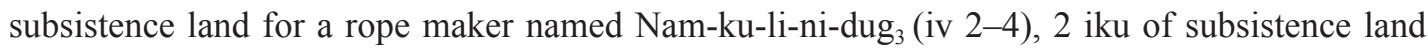
for a rope maker named $\mathrm{Uru}_{11}-\mathrm{ki}^{\mathrm{d}-\mathrm{dug}_{2}}$ (rev. i $\left.3^{\prime}-6^{\prime}\right)$, and $4 \mathrm{iku}$ of subsistence land for a rope maker named $\mathrm{Ur}-\mathrm{gu}_{2}$ (rev. ii $\left.3^{\prime}-6^{\prime}\right)$. Ur-gu $\mathrm{gu}_{2}$ was mentioned with certain amount of barley in another text (Erm 14371 [P225758] i 5-6), in which another rope maker whose name is broken played the role of deputy (maškim) in a transaction (ii 1-3).

\section{Al-la the Rope Maker}

A tug ${ }_{2}-\mathrm{du}_{8}$ named Al-la seems to have had a special position among his colleagues. DP 219 (L4) records that a ram was slaughtered for his wife Bara 2 -ir-nun in the kitchen when she gave birth to a child. ${ }^{60}$ This draws our attention because it reminds us of a similar record, that of Bara $_{2}-$ nam-tara, wife of Lugalanda, who gave birth to a daughter (Munus-sa ${ }_{6}$-ga) in the same year (Nik 1 209; DP 218). These are the only two women for whom records of childbirth have been preserved in the Presargonic $\mathrm{E}_{2}-\mathrm{MI}_{2}$ corpus. A question arises as to the identity of this Bara 2 -ir-

\footnotetext{
${ }_{52}\left[0.0 .3\right.$ Nin-igi-ga -teš $_{2}$-bi / šu- i $_{2}$ munus $]-a_{6} /$ Lugal-temen-da / e-da-ti in Nik 122 rev. ii 1-4.

53 0.0.3 Nin-igi-ga 2 -tešs - -bi / $\left[\mathrm{U}_{2}-\mathrm{U}_{2}\right]$ agrig-da / e-da-ti in DP 119 rev. i $12-$ ii 3 (UL2.4b); (ration amount) Nin-igi-ga ${ }_{2}$ te $\breve{s}_{2}$-bi/mu / šu-i i $_{2}$ munus-am ${ }_{6} / \mathrm{U}_{2}-\mathrm{U}_{2}$ / e-da-ti in TSA 18 rev. iii 16-iv 3 (UL3); DP 116 rev. iii 11-14 (UL4.7b).

${ }^{54}$ According to Magid $(2001,325)$, when texts talk about, for example, a barber living with another barber, a servant living with another servant, or a miller living with another miller, we are dealing with overseer-subordinate pairings. This might be the case with Lugal-temen the barber and the four barbers. However, we face a problem with $\mathrm{U}_{2}-\mathrm{U}_{2}$ because he is not described anywhere as a barber and is at one point identified as an agrig-official, provided that the restoration by CDLI is correct.

551 tug $_{2}-\mathrm{du}_{8}$ 0.2.0 in RTC 54 vi 11 (L6.2b).

${ }^{56} 4 \mathrm{lu}_{2}$ 0.2.0/ tug $_{2}-\mathrm{du}_{8}-$ me in Erm 14346 [P225753] iv 6'-7' $\left(\mathrm{UL5}^{2}\right)$; although the rubric of the text is broken, it is certain that this is a Type I text.

${ }^{57} 1 \operatorname{tug}_{2}-\mathrm{du}_{8}$ 0.1.2 / 3 tug $_{2}-\mathrm{du}_{8}$ 0.1.1 in DP 121 iii 12-iv 1 (UL6.6b).

582 gi kušs 3 tug $_{2}-$ du $_{8}$ in DP 622 rev. ii 5 (L2)

59 1 1/4 (iku) $\operatorname{gan}_{2} \operatorname{tug}_{2}-\mathrm{du}_{8}$ in HSS 338 iii 7.

${ }^{60} \mathrm{Bara}_{2}$-ir-nun / dam Al-la / tug 2 - $\mathrm{du}_{8}-\mathrm{ke}_{4} /$ dumu i $\mathrm{i}_{3}$-tu-da-a in DP 219 i $2-5$ (Rosengarten 1960, 342).
} 
nun, who received the same kind of record as the queen?

In a document dating two years earlier than DP 219, "Bara 2 -ir-nun, wife of Al-la" (VS 14 159 vi 10-11) was listed among the mašdaria-gift givers. Although Al-la's profession name is not indicated, he is most likely to be identified with Al-la the $\operatorname{tug}_{2}-\mathrm{du}_{8}$. Meanwhile the name Bara $_{2}$-ir-nun is found among Lugalanda's sisters (DP 127 ii 11: nin ensi ${ }_{2}-\mathrm{ka}-\mathrm{me}$ ), who were also lukur-priestesses (Steinkeller 1981, 84-85 n. 47). ${ }^{61}$ Being the ruler's sister would explain the high visibility conferred on Bara $_{2}$-ir-nu and the special attention paid to her childbirth. In the two documents where Bara $_{2}$-ir-nun was referred to as a lukur and received 72 sila of barley and 72 sila of emmer (RTC 61 iii 8-9; DP 134 iii 3-4), her future husband Al-la the rope maker was separately listed: in one (DP 134 rev. ii after the break) he was given 36 sila of barley and 36 sila of emmer, half of her rations. ${ }^{62}$ Al-la the rope maker cultivated leased land and 840 sila was his še-gub-ba "barley delivery" (DP 554 i 1-3). Someone who could marry the sister of the ruler must have himself belonged to the upper echelon of society.

\section{A Pair of a Male and a Female Rope Makers} E-ta-e ${ }_{11}$ and Nam-šita-mu-bi $i_{2}-$ dug $_{4}$

E-ta-e ${ }_{11}$ and Nam-šita-mu-bi ${ }_{2}-$ dug $_{4}$ were repeatedly listed as a pair of rope makers in Type II ration lists (L6.9-UL5.3b) in the following formula: ${ }^{63}$

$36 / 48$ sila E-ta-e ${ }_{11}$

$36 / 48$ sila Nam-šita-mu-bi ${ }_{2}-$ dug $_{4}$

$\operatorname{tug}_{2}-\mathrm{du}_{8}-\mathrm{me}$

Although Nam-šita-mu-bi ${ }_{2}-$ dug $_{4}$ was certainly a female name, she was never designated as * $\operatorname{tug}_{2}-$ $\mathrm{du}_{8}$ munus. $^{64}$ This can be contrasted with the cases of hairdressers ( $\check{\mathrm{s} u-\mathrm{i}_{2}}$ munus) and female doorkeepers ( $\mathrm{i}_{3}-\mathrm{du}_{8}$ munus), in which feminine gender marking was usually (but not always) made. Both E-ta-e ${ }_{11}$ and Nam-šita-mu-bi ${ }_{2}-d_{u g}$, regardless of their gender, received the same amount of barley rations, which was either 36 sila or 48 sila. At a certain point Nam-šita-mu-bi ${ }_{2}-$ $\operatorname{dug}_{4}$ disappears from the ration lists, whereas E-ta-e ${ }_{11}$ kept his job. ${ }^{65}$

\section{Doorkeepers $\left(\mathbf{i}_{3}-\mathbf{d u}_{8}\right)$}

As shown concerning the barbers and the rope makers, a group of doorkeepers can be recognized that consisted of landed males belonging to higher socio-economic strata on the one hand, and landless males and females working for the $\mathrm{E}_{2}-\mathrm{MI}_{2}$ on the other.

\section{Doorkeepers from Higher Socio-Economic Strata}

\section{Doorkeepers with a Specific Title}

${ }^{61}$ See also Sharlach 2008.

${ }^{62}$ Cf. RTC 61 rev. iv $15-\mathrm{v} 4$.

${ }^{63}$ VS 2571 rev. i 10-12; VS 2511 rev. i 6-8; RA 71102 rev. ii 3-5; MVN 32 rev. ii 6-8; HSS 316 viii 4-6; Nik 1 9 viii 8-10; DP 113 rev. i 16-18; HSS 317 rev. ii 17 - iii 2; FAOS 15/2 121 rev. iii 9-11; FAOS 15/2 120 rev. 4-6; TSA 14 rev. i 14-ii 2; TSA 15 rev. ii 15 - iii 2; DP 114 rev. ii 8-10.

${ }_{64}^{64}$ Prentice $(2010,41)$ does not specify Nam-šita-mu-bi ${ }_{2}-$ dug $_{4}$ as being female.

${ }^{65}$ TSA 17 rev. ii 10-11 (UL6.[ ]b); HSS 318 ix 10-11 (UL6.12b). 
Doorkeepers with a specific title, listed below, are collected from Type I ration lists and documents of land allotment, leaseholds, work assignments, and gift-receiving. ${ }^{66}$

$$
\begin{aligned}
& \mathrm{Lu}_{2}-\mathrm{zi} / \mathrm{i}_{3}-\mathrm{du}_{8} \mathrm{e}_{2}-\mathrm{PA} \text { (gidri)-ka }{ }^{67} \\
& \text { Lugal-pirig / } \mathrm{i}_{3}-\mathrm{du}_{8} \text { nam-dumu }{ }^{68} \\
& \text { Lugal-ušur }{ }_{3}-\mathrm{ra} / \mathrm{i}_{3}-\mathrm{du}_{8}{ }^{\mathrm{d}} \mathrm{Ba}-\mathrm{u}_{2}{ }^{69} \\
& \text { Lum-ma-teš } \check{2}_{2}-\mathrm{mu} / \mathrm{i}_{3}-\mathrm{du}_{8} \mathrm{e}_{2}-\mathrm{gal}^{70} \\
& \mathrm{Na}-\mathrm{ni} / \mathrm{i}_{3}-\mathrm{du}_{8} \mathrm{Uru}_{11}{ }^{\mathrm{ki} 71} \\
& \text { Ur-du } 6 / \mathrm{i}_{3}-\mathrm{du}_{8} \mathrm{e}_{2}-\mathrm{gal}^{72} \\
& \text { Ur- }{ }^{\mathrm{d}} \text { Dumu-zi / } \mathrm{i}_{3}-\mathrm{du}_{8} \mathrm{bad}_{3}{ }^{73} \\
& \text { Ur- }{ }^{\mathrm{d}} \operatorname{Igi}\left(-\mathrm{ama}-\breve{s e}_{3}\right) / \mathrm{i}_{3}-\mathrm{du}_{8} \mathrm{bad}_{3}{ }^{74} \\
& \text { Ur- }{ }^{\mathrm{d}} \mathrm{Nin}-\mathrm{gir}_{2} \text {-su } / \mathrm{i}_{3}-\mathrm{du}_{8} \text { Ti-ra-aš }{ }_{2}{ }^{\mathrm{ki}} 75 \\
& \text { Ur-šubur } / \mathrm{i}_{3}-\mathrm{du}_{8} \text { ganun-mah }{ }^{76}
\end{aligned}
$$

\section{Ur-du ${ }_{6}$ the Doorkeeper of the Palace}

$\mathrm{Ur}^{-} \mathrm{du}_{6}$ the doorkeeper of the palace ${ }^{77}$ is without doubt the most prominent figure among the highranking doorkeepers. One of his earliest attestations is found in E2, where he appears as a witness in a sales document (RTC $17=$ SRU 44). Next, he occurs in the records of wool distribution to "the supervisors and the igi-nigin $n_{2}$-people" (ugula-ne $\operatorname{lu}_{2}$ igi-nigin $_{2}$-ne) dating from L2 to $\mathrm{UE}^{78}$ and then, in Type I (barley or emmer) ration lists dating from L6.2b to UL6.11b. ${ }^{79}$ His barley ration was normally 36 sila (with the exception of 72 sila on two occasions) and his emmer ration was 12 sila. Corresponding to his occurrence in Type I lists, he was allocated subsistence land ${ }^{80}$ and assigned obligatory work such as canal maintenance, harvesting the ruler's fields, and so on. ${ }^{81}$ He was also listed in one document dating from UL3 (DP 130 vii 11-12) classified as $l_{2}$ ninda $\operatorname{gan}_{2}$ maš-ba ${ }^{\mathrm{d}} \mathrm{Ba}_{-}{ }_{2}{ }^{82}$ and in the other dating from UL4 (CT 5037 rev. ii 1-2) as še-gar ziz ${ }_{2}$-gar $\mathrm{Sa}_{2}-\mathrm{dug}_{4}$ iti-da ${ }^{\mathrm{d}} \mathrm{Ba}-\mathrm{u}_{2} \cdot{ }^{83}$ In the latter, he was one of the professionals who, though not a herdsman,

${ }^{66}$ In a document dealing with reed-cutting, CDLI restores: [Ur- $\left.{ }^{\mathrm{d}}\right] \mathrm{Pa}-\left[\mathrm{bil}{ }_{3}-\mathrm{sag}\right] / \mathrm{i}_{3}-\mathrm{du}_{8} \mathrm{e}\left[\check{\mathrm{s}}_{3}\right]$ (DP 352 ii 1-2); cf. a doorkeeper named $\mathrm{Ur}_{-}^{\mathrm{d}}{ }^{\mathrm{Pa}}$-bil ${ }_{3}$-sag who appeared on the Type II ration lists.

${ }^{67}$ VS 14180 rev. iii 13-iv 3.

${ }^{68}$ Nik 163 rev. i 8-9.

${ }^{69}$ Nik 1102 i $4-5$.

${ }^{70}$ VS 14181 v 6-7; DP 622 iv 5-6; DP 623 rev. iii 9-iv 1; DP 624 iv 1-2; Nik 179 iii 5-6.

${ }^{71}$ TSA 7 rev. vi 4-6.

72 See below.

${ }^{73}$ VS 2715 ii 3-4.

${ }^{74}$ VS 2521 i 1-3; DP 587 iii 3-4.

75 DP 92 rev. ii 3-4; DP 354 i 1-3; VS 2589 rev. i 6-7; TIM 994 ii' 3'-6'; Tiraš was one of the four temples situated in the city of Lagaš (Suter 2000, 87).

${ }^{76}$ VS 2561 ii $2-3$.

${ }^{77}$ DP 623 rev. iii 8-iv 1; DP 624 iii 8-iv 2.

${ }_{79}$ DP 192; VS14 181; DP 193; DP 194; also note VS 27 34, another record of wool given to Ur-du 6 .

79 RTC 54; HSS 3 5; HSS 3 6; HSS 3 7; Nik 1 13; HSS 3 8; FAOS 15/2 118; HSS 3 9; HSS 3 10; HSS 3 11; FAOS 15/2 68; FAOS 15/2 67; DP 121; BIN 8 354; HSS 3 13; HSS 3 12; Erm 14004 [P315467]; Erm 14346 [P225753]; Erm 14349 [P225756].

${ }^{80}$ VS 2540 (L3); VS 2570 (UL1); HSS 340 (UL1); Erm 15776 [P225761]; HSS 338.

${ }^{81}$ DP 622 (L2); DP 623 (L3); DP 624 (L3); VS 2520 (L6); VS 2599 (L6); VS 25 41; DP 637 (UL1); TSA 23 (UL1); VS 2574 (UL1); VS 2579 (UL2); DP 638 (UL2); VS 2796 (UL2); DP 647 (UL4).

82 "Leute der Baba, denen das 'Brot' der 'Zinsfelder' zugeteilt wird"' (Selz 1995, 72).

83 "Gerstenlieferungen (und) Emmerlieferungen, regelmäßige Aufwendungen des Monats der Baba" (Bauer 1967, 190). 
took care of animals belonging to the $\mathrm{E}_{2}-\mathrm{MI}_{2}$ and received the grain with which to feed them. ${ }^{84}$

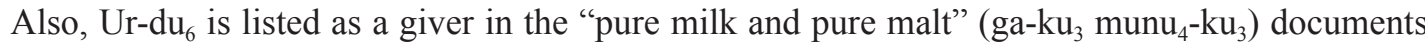
(see $\S$ III.1).

\section{Male and Female Doorkeepers}

From Type II and various ration lists other than Type I we can collect the names of twelve male and three female doorkeepers. It seems that four to ten doorkeepers-sometimes only men and sometimes a mixed group of men and women—worked at a given time.

\section{Male Doorkeepers}

Of twelve male doorkeepers belonging this group, I will discuss Amar-šuba 3 , Nam-mah(-ni), $\mathrm{Nig}_{2}$-gur ${ }_{11}$-kur-ra, and Ur- Inanna.

\section{Amar-šuba ${ }_{3}$, Nam-mah(-ni), and Nig ${ }_{2}-$ gur $_{11}-k u r-r a$}

Amar-šuba ${ }_{3}$ headed the section of doorkeepers and was the only doorkeeper in the extant Type II lists who received 36 sila of barley (L6.9b-L6.12b). ${ }^{85} \mathrm{Nam}-\mathrm{mah}(-\mathrm{ni})$ and $\mathrm{Nig}_{2}$ - gur $_{11}$-kurra occupied the second and the third place respectively in the group. When Amar-šuba 3 was dropped from the list, Nam-mah(-ni) took his place at the head, and $\mathrm{Nig}_{2}$ - gur $_{11}$-kur-ra rose to the second place (UE2b-UE6b). ${ }^{86}$ Later, the order of these two was reversed, with $\mathrm{Nig}_{2}$ - gur $_{11}$-kurra preceding Nam-mah(-ni) (UL2.8b-UL5.3b). ${ }^{87}$ Both of them received either 18 or 24 sila of barley rations. $^{88}$

$\mathrm{Nig}_{2}$ - - $u r_{11}$-kur-ra and Nam-mah(-ni) are also found in the Type I ration list dated to UE2b, both receiving 24 sila of barley. ${ }^{89}$ This is surprising because, as we have seen above, they occur in the Type II list dating from the very same UE2b: their barley rations were also recorded as 24 sila each. Was this double notation a scribal mistake? Possibly, but before dismissing it as archival confusion, we must consider a couple of other documents.

One is DCS 8, dating from Lugal-an-da-nu-hun-ga 1 (= L1). This is a record of emmerflour rations distributed to the $\operatorname{sur}_{\mathrm{x}}$ (ERIM) on the occasion of the festival of the goddess ${ }^{\mathrm{d}} \mathrm{Ba}-\mathrm{u}_{2}$ (ziz ${ }_{2}$-ba ERIM-ra ezem ${ }^{\mathrm{d}} \mathrm{Ba}-\mathrm{u}_{2}-\mathrm{ka}$ ). Deimel (apud Prentice 2010, 75 n. 323) equated the sur ${ }_{\mathrm{x}}$ with those who held subsistence land $\left(\mathrm{lu}_{2}\right.$ šuku dab ${ }_{5}$-ba).$^{90}$ This document lists the doorkeeper Nam-

${ }^{84}$ Two more doorkeepers, Lugal-sag and Lugal-pirig ( $\mathrm{i}_{3}-\mathrm{du}_{8}$ nam-dumu), had a similar task: the former is mentioned in Nik 167 (E4), DP 145 (L1), BIN 8372 (L1.6g), VS 1477 (L1.10g), and Nik 162 (L1.12g); and the latter in Nik 1 63 (UL3.1g).

${ }^{85}$ VS 2571 (L6.9b); VS 2511 (L6.10b); RA 71102 (L6.12b).

${ }^{86}$ MVN 32 (UE2b); HSS 315 (UE5b); HSS 316 (UE6b).

${ }^{87}$ DP 113 (UL2.8b); CT 5036 (UL3.6b); HSS 317 (UL3.10b); FAOS 15/2 120 (UL4.2b); TSA 14 (UL4.4b); TSA 15 (UL4.7b); DP 114 (UL5.3b).

${ }^{88}$ The standard ration for doorkeepers was 18 or 24 sila, with the exception of Amar-šuba . Regarding the low amount of rations, Prentice (2010, 44 n. 218) comments that "[p]ossibly doorkeeping was not considered a very arduous or skilled occupation" and refers to the possibility suggested by Sallaberger that "the doorkeepers were old men." However, low rations are not found only here. According to Maekawa (1980, 89), female weavers were usually given 18 or 24 sila of barley per month in Presargonic Lagaš; we have seen that the low-ranking male and female barbers also often received 18 or 24 sila.

${ }^{89}$ 0.0.4 $\mathrm{Nig}_{2}$ - gur $_{11}$-kur-ra / 0.0.4 Nam-mah / $\mathrm{i}_{3}-\mathrm{du}_{8}$-me in HSS 36 rev. iii 2-4.

${ }^{90}$ However, it may not have been limited to šuku-land holders because two landless barbers are also included in the sur in DCS 8 (see $\S$ III. 4). This requires further study. 
mah-ni among the ration receivers. ${ }^{91}$ Another relevant document is DP 623, dating from L3. This was a record of assignments of canal maintenance work, where the doorkeeper $\mathrm{Nig}_{2}$-gur ${ }_{11}$-kurra was mentioned, ${ }^{92}$ as well as the palace doorkeepers $U r-\mathrm{du}_{6}$ and Lum-ma-teš $\check{2}_{2}-\mathrm{mu}$. Since this type of obligatory work was supposed to be carried out by šuku-holders, it is no surprise to find Ur-du $\mathrm{d}_{6}$ and Lum-ma-teš $\check{2}_{2}$-mu (see $\S$ VI.1). But what about $\mathrm{Nig}_{2}$-gur ${ }_{11}$-kur-ra? If this person was to be counted as a šuku-holder, his case and that of Nam-mah(-ni) might indicate changes that occurred in their socio-economic status.

\section{Ur- Inanna}

Ur- ${ }^{\mathrm{d}}$ Inanna occurs in the Type II ration lists dating from $\mathrm{L}^{93}$ and from UL6, ${ }^{94}$ receiving 24 sila of barley. Between these years, he is mentioned as a giver following the elite doorkeeper $\mathrm{Ur}^{-\mathrm{du}_{6}}$ in two documents of "pure milk and pure malt" dated to UL1 and UL2, respectively. ${ }^{95}$ Again in UL2, Ur- ${ }^{\mathrm{d}}$ Inanna occurs among those to whom Sasa, wife of Urukagina, sold sheep hide with fleece (kuš-udu-bar-gal $\left.{ }_{2}-1 \mathrm{a}\right){ }^{96}$

\section{Female Doorkeepers}

The following three female doorkeepers are attested in the corpus. ${ }^{97}$

\section{Nam-šita(-mu-bi $\left.i_{2}-d u g_{4}\right)$, Nin-tigi $_{x}-n i-d u g_{3}$, and Nin-en-še $e_{3}-n u-k a r_{2}-k_{a r}$}

Nam-šita-mu-bi ${ }_{2}-$ dug $_{4}$, abbreviated as Nam-šita, and her child are mentioned in a barley ration list of "the personnel of prince-ship of the god Igalim" ( $\left(\mathrm{lu}_{2}\right.$ nam-dumu ${ }^{\mathrm{d}} \mathrm{Ig}$-alim-ka) dating from UL1, with 24 sila and 12 sila, respectively (Nik 118 rev. iii 6-8). In a wool ration list dating from the same year (UL1), Nam-šita received 3 minas and her daughter received $1 / 2$ mina (VS 2721 iii 5-7). ${ }^{98}$ In the following years, UL2 and UL3, the two emmer-flour ration lists of "the friends of royal children" (ušur 3 nam-dumu) listed her with 18 sila (DP 128 v 8-9; DP 129 rev. i 1-2). On the one hand, these texts seem to indicate that Nam-šita-mu-bi ${ }_{2}-d_{u g}$ was at some point related to a household of royal children. ${ }^{99}$ On the other hand, she occurs in Type II barley ration lists dating from UL2.8b to UL6.4b, receiving either 18 or 24 sila and accompanied by her daughter with 12 sila. $^{100}$

${ }^{91}$ 0.0.3 Nam-mah-ni / $\mathrm{i}_{3}-\mathrm{du}_{8}$ in DCS 8 rev. v 2-3.

922 gi Nig - gur $_{11}-$ kur-ra $/ i_{3}-$ du $_{8}$ in DP 623 rev. iv 10-v 1; cf. DP 624 v 3-4, which contains the same information (2 gi $\mathrm{Nig}_{2}$-gur 11 -kur-ra/ $\mathrm{i}_{3}-\mathrm{du}_{8}$ ); DP 624 - the obverse seems to have been partially crossed out and on the reverse three right-hand columns were left uninscribed although the summary information ( $\breve{\text { sul-nigin }} 2 \ldots)$ was placed in the two lefthand columns - was this tablet discarded in antiquity?

${ }^{93}$ VS 25 71; VS 2511 ; RA 71102.

${ }^{94}$ DP 115; FAOS 15/2 122; Erm 14348 [P225755]; TSA 16; TSA 17; HSS 318.

${ }^{95}$ DP 133 rev. vi 6-10; TSA 5 rev. iv $12-\mathrm{v} 4$.

${ }^{96}$ Nik 1230 (Selz 1989, 457).

${ }^{97}$ In an earlier document, dating from L2, a female doorkeeper was given wool rations along with four male doorkeepers, but they are all unnamed (DP 175 iv 1-2).

${ }^{98}$ Note that in this text four male doorkeepers, who received 2 mina of wool each (i 7), were counted among the men of Ur-tar (ii 1: $\operatorname{lu}_{2}$ Ur-tar-me). It is quite possible to identify Ur-tar with Ur-tar-sir ${ }_{2}$ - $\operatorname{sir}_{2}$-ra, one of Lugalanda's sons (DP 175 rev. ii 2-5; DP 59 vi 11-12); cf. Ur-tar- $\operatorname{sir}_{2}-\operatorname{sir}_{2}$-ra, the son of Enentarzi (DP 173 rev. ii 2-6).

${ }_{99}$ Note also that Lugal-pirig was $\mathrm{i}_{3}-\mathrm{du}_{8}$ nam-dumu "doorkeeper of prince-ship" (Nik 163 rev. i 9; dating from UL3); according to Selz $\left(1989,271\right.$ sub 8: 8-9) $\mathrm{i}_{3}-\mathrm{du}_{8}$ nam-dumu is attested only here.

${ }^{100}$ DP 113; CT 50 36; FAOS 15/2 121; HSS 3 17; FAOS 15/2 120; TSA 14; Nik 12 ; TSA 15; DP 114; DP 115 ; FAOS $15 / 2122$. 
Nin-tigi $i_{x}$-ni-dug ${ }_{3}$ joined Nam-šita-mu-bi ${ }_{2}-\mathrm{dug}_{4}$ and these two women are listed side by side with the gender marking "(they are) women" (munus-me), immediately following their male counterparts (nita-me) in Type II lists (UL3.6b-UL5.3b). The third female doorkeeper was named Nin-en-še ${ }_{3}-n u-k_{2} r_{2}-k_{2} r_{2}$. She was recorded as an orphan living with the doorkeeper Igi${ }^{\mathrm{d}} \mathrm{Ba}-\mathrm{u}_{2}-\mathrm{S}_{3}$ for a while (UL4.7b-UL6.8b) ${ }^{101}$ and lastly appears as a female doorkeeper in a ration list dating from UL6.12b (HSS 318 rev. i 10-11). Nin-tigi -ni-dug $_{3}$ and Nin-en-še ${ }_{3}$-nu-kar ${ }_{2}-k_{2} r_{2}$ were given 18 sila each.

\section{Conclusions}

Both men and women worked in the professions discussed in this paper, $\breve{s} u-i_{2}, \operatorname{tug}_{2}-\mathrm{du}_{8}$, and $\mathrm{i}_{3}$ $\mathrm{du}_{8}$. A pattern seems to be discernible, namely that each group was comprised of men who held subsistence land and thus were listed in Type I ration lists, and men and women who held no land but received barley rations every month, and thus were listed in Type II or IV lists. With regard to Type II, while male and female šu- $\mathrm{i}_{2}$ were registered on the $\mathrm{sa}_{3}-\mathrm{dub}-\mathrm{e}_{2}$-gal "tablets of the palace," male and female tug ${ }_{2}-\mathrm{du}_{8}$ and $\mathrm{i}_{3}-\mathrm{du}_{8}$ were registered on the ša $\mathrm{a}_{3}$-dub-didli "various tablets"; what the different register meant in reality we can only guess. Assuming that the ration lists and land allotment texts reflect the socio-economic status of a receiver, these documents should in turn reflect the workforce hierarchy.

\section{Acknowledgement}

This article is a concise version of my two papers read in 2013 at the second and third workshops of the REFEMA Research Project. I am most grateful to Francis Joannès and his French colleague who organized the fruitful workshops in Nanterre and Carqueirainne (2012-2014). I also thank Frederick W. Knobloch for helpful discussion and comments while preparing articles.

\section{Bibliography}

Asher-Greve, J. M. 1985: Frauen in altsumerischer Zeit, Bibliotheca Mesopotamica 18, Malibu: Undena Publications.

Balke, T. 2011: "Eine neue altsumerische Verwaltungsurkunde aus Ĝirsu," AoF 38, 3-14.

Bartash, V. 2014: “E $\mathrm{E}_{2}-\mathrm{mi}_{2}-$ 'Women's Quarters': The Earliest Written Evidence,” in F. Buccellati et al. (eds.), House and Household Economies in $3^{\text {rd }}$ Millennium B.C.E. Syro-Mesopotamia, Oxford: Archaeopress, 9-20.

Bauer, J. 1967: “Altsumerische Wirtschaftstexte aus Lagash,” Inaugural-Dissertation zur Erlangung der Doktorwürde der Philosophischen Fakultät der Julius-Maximilians-Universität zu Würzburg.

Beld, S. G. 2002: “The Queen of Lagash: Ritual Economy in a Sumerian State,” Ph. D. dissertation, The University of Michigan.

Brunke, H. 2011: "Feasts for the Living, the Dead, and the Gods," in K. Radner and E. Robson (eds.), The Oxford Handbook of Cuneiform Culture, Oxford: Oxford University Press, 167-183.

Buccellati, G. and M. Kelly-Buccellati 1995-96: "The Royal Storehouse of Urkesh: The Glyptic Evidence from the Southwestern Wing," AfO 42-43, 1-32.

Budin, S. L. 2011: Images of Woman and Child from the Bronze Age: Reconsidering Fertility, Maternity, and Gender in the Ancient World, Cambridge: Cambridge University Press.

Cohen, M. E. 1993: The Cultic Calendars of the Ancient Near East, Bethesda, MD: CDL Press.

Deimel, P. A. 1928: “Die Lohnlisten aus der Zeit Urukaginas und seines Vorgängers,” Orientalia Series Prior 34-35, $1-122$.

${ }^{101}$ TSA 15; DP 114; DP 115; FAOS 15/2 122; Erm 14348 [P225755]; TSA 16; TSA 17. 
Ellison, R. 1981: "Diet in Mesopotamia: The Evidence of the Barley Ration Texts (c. 3000-1400 B.C.)," Iraq 43, 3545.

Foxvog, D. 2011: “Aspects of Name-Giving in Presagonic Lagash,” in W. Heimpel and G. Frantz-Szabó (eds.), Strings and Threads: A Celebration of the Works of Anne Draffkorn Kilmer, Winona Lake, IN: Eisenbrauns, 59-97.

Frayne, D. R. 1993: Sargonic and Gutian Periods (2334-2113 BC), RIME 2, Toronto: University of Toronto Press.

Gelb, I. 1975: "Homo Ludens in Early Mesopotamia," StOr 46, 43-75.

Goodnick Westenholz, J. 2013: "In the Service of the Gods: The Ministering Clergy," in Harriet Crawford (ed.), The Sumerian World, London: Routledge, 246-274.

Hallo, W. W. 1973: "The Date of the Fara Period: A Case Study in the Historiography of Early Mesopotamia," OrNS 42, 228-238.

Hruška, B. 1988: “Zu den Produktionsverhältnissen in der altsumerischen Landwirtschaft,” in J. Herrmann and J. Köhn (eds.), Familie, Staat und Gesellschaftsformation, Berlin: Akademie-Verlag, 328-334.

Jagersma, A. 2007: “The Calendar of the Funerary Cult in Ancient Lagash,” BiOr 64, 289-307.

Karahashi, F. forthcoming: "Women and Land in the Presargonic Lagaš Corpus," in B. Lion and C. Michel (eds.), The Role of Women in Work and Society in the Ancient Near East, Berlin and Boston: De Gruyter.

Kleinerman, A. 2013: "The Barbers of Iri-Saĝrig," in S. Garfinkle and M. Molina (eds.), From the 21 $1^{\text {st }}$ Century B.C. to the $21^{\text {st }}$ Century A.D.: Proceedings of the International Conference on Neo-Sumerian Studies Held in Madrid, 22-24 July 2010, Winona Lake, IN: Eisenbrauns, 301-311.

Maeda, T. 1984: "Work Concerning Irrigation Canals in Pre-Sargonic Lagash," ASJ 6, 33-53.

Maekawa, K. 1973-74: “The Development of the é-mí in Lagash during Early Dynastic III,” Mesopotamia 8-9, 77144.

Maekawa, K. 1980: "Female Weavers and Their Children in Lagash: Pre-Sargonic and Ur III," ASJ 2, 81-125.

Maekawa, K. 1987: “Collective Labor Service in Girsu-Lagash: The Pre-Sargonic and Ur III Periods,” in M. A. Powell (ed.), Labor in the Ancient Near East, AOS 68, New Haven, CT: American Oriental Society, 49-71.

Maekawa, K. 1996: “The Governor's Family and the "Temple Households" in Ur III Girsu," in K. R. Veenhof (ed.), House and Households in Ancient Mesopotamia, PIHANS 78 (= RAI 40), Leiden and Istanbul: Nederlands Historisch-Archaeologisch Instituut, 171-179.

Magid, G. 2001: "Micromanagement in the $\mathrm{e}_{2}-\mathrm{mi}_{2} /{ }^{\mathrm{d}} \mathrm{Ba}-\mathrm{u}_{2}$ : Notes on the Organization of Labor at Early Dynastic Lagash," in T. Abusch et al. (eds.), Historiography in the Cuneiform World. RAI 44, part 1, Bethesda, MD: CDL Press, 313-328.

Molina, M. 2008: “New Ur III Court Records Concerning Slavery,” in P. Michalowski (ed.), On the Third Dynasty of Ur: Studies in Honor of Marcel Sigrist, JCS Supplemental Series, 1, Boston: American Schools of Oriental Research, 125-143.

Pecha, L. 2011: "The Official Called ŠU.I (gallābum) in the Latter Part of the Old Babylonian Period," in L. Vacín (ed.), $U_{4}$ DU $U_{11}$-GA-NI SÁ MU-NI-IB-DU $U_{11}$ : Ancient Near Eastern Studies in Memory of Blahoslav Hruška, Dresden: ISLET-Verlag, 169-181.

Prentice, R. 2010: The Exchange of Goods and Services in Pre-Sargonic Lagash, AOAT 368, Münster: Ugarit-Verlag.

Rosengarten, Y. 1960: Le concept sumérien de consommation dans la vie économique et religieuse: Étude linguistique et sociale d'après les textes présargoniques de Lagaš, Paris: E. de Boccard.

Sallaberger, W. and F. Huber-Vulliet 2005: "Priester. A. I. Mesopotamien,” RlA 10: 617-640.

Sallaberger, W. and A. Pruß 2015: "Home and Work in Early Bronze Age Mesopotamia: 'Ration Lists' and 'Private Houses' at Tell Beydar/Nabada," in P. Steinkeller and M. Hudson (eds.), Labor in the Ancient World, International Scholars Conference on Ancient Near Eastern Economies, 5, Dresden: ISLET-Verlag, 69-136.

Sallaberger, W. and I. Schrakamp 2015: "I.5. The Presargonic Period," in Walther Sallaberger and Ingo Schrakamp (eds.), History and Philology, Associated Regional Chronologies for the Ancient Near East and the Mediterranean, 3 , Turnhout: Brepols, 67-84.

Selz, G. 1989: Altsumerische Verwaltungstexte aus Lagaš, Teil 1, Die altsumerischen Wirtschaftsurkunden der Ermitage zu Leningrad, FAOS 15/1, Stuttgart: Franz Steiner Verlag.

Selz, G. 1993: Altsumerische Verwaltungstexte aus Lagaš, Teil 2, Altsumerische Wirtschaftsurkunden aus amerikanischen Sammlungen, 2. Abschnitt, FAOS 15/2-2, Stuttgart: Franz Steiner Verlag.

Selz, G. 1995: Untersuchungen zur Götterwelt des altsumerischen Stadtstaates, Occasional Publications of the Samuel Noah Kramer Fund, 13, Philadelphia: The University of Pennsylvania Museum.

Selz, G. 2010: “'He put in order the accounts...': Remarks on the Early Dynastic Background of Administrative Reorganizations in the Ur III State," in L. Kogan et al. (eds.), City Administration in the Ancient Near East, RAI 53, 
vol. 2, Babel und Bibel 5, Winona Lake, IN: Eisenbrauns, 5-30.

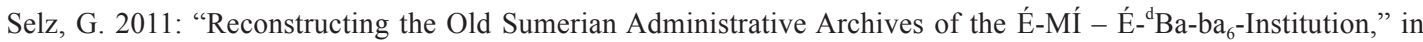
G. Barjamovic et al. (eds.), Akkade Is King. A Collection of Papers by Friends and Colleagues Presented to Aage Westenholz on the Occasion of His 70th Birthday $15^{\text {th }}$ of May 2009, PIHANS 118, Leiden: Nederlands Instituut voor het Nabije Oosten, 273-286.

Sharlach, T. M. 2008: "Priestesses, Concubines, and the Daughters of Men: Disentangling the Meaning of the Word lukur in Ur III Times," in P. Michalowski (ed.), On the Third Dynasty of Ur: Studies in Honor of Marcel Sigrist, Boston: American Schools of Oriental Research, 177-183.

Steinkeller, P. 1981: "More on the Ur III Royal Wives," ASJ 3, 77-92.

Steinkeller, P. 1999a: "Land-Tenure Conditions in Third-Millennium Babylonia: The Problem of Regional Variation," in M. Hudson and B. A. Levine (eds.), Urbanization and Land Ownership in the Ancient Near East, Peabody Museum Bulletin 7, Cambridge, MA: Harvard University, 289-321.

Steinkeller, P. 1999b: "On Rulers, Priests and Sacred Marriage: Tracing the Evolution of Early Sumerian Kingship," in Kazuko Watanabe (ed.), Priests and Officials in the Ancient Near East: Papers of the Second Colloquium on the Ancient Near East-The City and its Life, Held at the Middle Eastern Cultural Center in Japan (Mitaka, Tokyo, March 22-24, 1996), Heidelberg: Universitätsverlag C. Winter, 103-137.

Suter, C. E. 2000: Gudea's Temple Building: The Representation of an Early Mesopotamian Ruler in Text and Image, Groningen: Styx Publications.

Suter, C. E. 2007: "Between Human and Divine: High Priestess in Images from the Akkad to the Isin-Larsa Period," in J. Cheng and M. H. Feldman (eds.), Ancient Near Eastern Art in Context: Studies in Honor of Irene J. Winter by her Students, Leiden: Brill, 317-361.

Visicato, G. 2011: "The Careers of Some Bureaucrats in ED IIIB and Sargonic Girsu," in G. Barjamovic et al. (eds.), Akkad is King: A Collection of Papers by Friends and Colleagues Presented to Aage Westenholz on the Occasion of His $70^{\text {th }}$ Birthday $15^{\text {th }}$ of May 2009, PIHANS 118, Leiden: Nederlands Instituut voor het Nabije Oosten, 301-313.

Waetzoldt, H. 1987: “Compensation of Craft Workers and Officials in the Ur III Period," in M. A. Powell (ed.), Labor in the Ancient Near East, New Haven, CT: American Oriental Society, 117-141.

Waetzoldt, H. 1988: "Die Situation der Frauen und Kinder anhand ihrer Einkommensverhältnisse zur Zeit der III. Dynastie von Ur," AoF 15, 30-44.

Waetzoldt, H. 2007: "The Use of Wool for the Production of Strings, Ropes, Braided Mats, and Similar Fabrics," in C. Gillis and M.-L. B. Nosch (eds.), Ancient Textiles: Production, Craft and Society: Proceedings of the First International Conference on Ancient Textiles, Held at Lund, Sweden, and Copenhagen, Denmark, on March 19-23, 2003, London: Oxbow Books, 112-121.

Yamamoto, S. 1980: “The 'Agricultural Year' in the Pre-Sargonic Girsu-Lagash (II)," ASJ 2, 169-195.

Yamamoto, S. 1981: “The lú-KUR 6 -dab -ba People in the é-mí-é-'Ba-Ú in Pre-Sargonic Lagash,” ASJ 3, $93-110$. 